\title{
FAKTOR - FAKTOR YANG MEMPENGARUHI PRODUKTIVITAS KERJA PEGAWAI PADA KANTOR PENGADILAN TATA USAHA NEGARA MAKASSAR
}

\author{
Samsul Risal', Dewi Fatimah², Ali Imran Jamal ${ }^{3}$. \\ Program Studi Manajemen Fakultas Ekonomi dan Bisnis \\ Universitas Muhammadiyah Makassar \\ (dewifatimah@gmail.com)
}

\begin{abstract}
ABSTRAK
Tujuan penelitian ini adalah Untuk mengetahui pengaruh faktor pendidikan terhadap produktivitas kerja pegawai pada Pengadilan Tata Usaha Negara Makassar dan untuk mengetahui pengaruh faktor pelatihan terhadap produktivitas kerja pegawai pada Pengadilan Tata Usaha Negara Makassar. Penelitian ini dilaksanakan di Pengadilan Tata Usaha Negara Makassar. Teknik sampling yang digunakan dalam penelitian ini adalah sampling jenuh. Sampling jenuh adalah teknik Penentuan sampel bila semua anggota populasi degunakan sebagai sampel pengambilan sampel pada penelitian ini dilakukan secara Accidetal Sampling yaitu teknik pengambilan sampel yang dapat dilakukan sewaktu-waktu sampai jumlah sampel (quota) yang diinginkan terpenuhi, instrument penelitian menggunakan kuesioner, dengan jumlah responden 50 orang. Metode analisis data yang digunakan adalah uji validitas, reliabilitas, analisis regresi berganda, analisis korelasi, koefisien determinasi, uji-t dan uji-f dengan menggunakan SPSS 23 for windows. Hasil penelitian menunjukkan bahwa variabel pendidikan dan pelatihan dengan produktivitas kerja pegawai pada Pengadilan Tata Usaha Negara Makassar, yang menunjukkan uji validitas lebih besar dari $r_{\text {tabel }} 0,30$ (valid), uji reliabilitas diperoleh Cronbach's alpha $(\alpha)>$ 0,60 dapat dikatakan reliable., uji regresi linier berganda $Y=-1.039+0,335 X_{1}+$ $0,464 \mathrm{X}_{2}$ (berpengaruh positif, koefisien determinasi 0,623 . Dari hasil penelitian uji $\mathrm{t}$ untuk pendidikan $\mathrm{t}_{\text {hitung }}=1,282$. Untuk pelatihan $\mathrm{t}_{\text {hitung }}=2.152$. sedangkan $\mathrm{t}_{\text {tabel }}$ $=2.010$. dapat dilihat bahwa variabel pelatihan yang berpengaruh signifikan karena $t_{\text {hitung }}>t_{\text {tabel. }}$. Koefisien determinasi yang diperoleh sebesar 0,623 artinya bahwa terdapat pengaruh pendidikan dan pelatihan terhadap produktivitas kerja pegawai sebesar $62,3 \%$
\end{abstract}

Kata Kunci : Pendidikan, Pelatihan dan Produktivitas Kerja Pegawai.

\section{PENDAHULUAN}

\section{Latar Belakang}

Kualitas sumber daya pegawai sangat diperlukan, hal ini sejalan dengan pengenalan ilmu dan teknologi baru, sehingga peningkatan kualitas sumber daya pegawai perlu dilakukan secara terencana, terarah, dan berkesinambungan dalam rangka meningkatkan kemampuan dan profesionalisme dalam bekerja. Sasaran dari pengembangan kualitas sumber daya pegawai adalah untuk 
meningkatkan kinerja operasional pegawai dalam melaksanakan tugas-tugas pemerintah. Selain itu peningkatan kualitas sumber daya pegawai dapat berdampak pula pada peningkatan produktivitas kerja pegawai. Sumber daya pegawai merupakan asset utama dalam instansi yang menjadi perencana dan pelaku aktif dari setiap aktivitas organisasi. Adapun pihak manajemen sangat menyadari bahwa peran serta pegawai pada suatu instansi harus mengikuti perkembangan dan tuntunan teknologi yang sesuai dengan kebutuhan instansi.

Pencapaian kebutuhan dan keinginan tersebut haruslah diikuti dengan peningkatan pengetahuan, keterampilan dan sikap manusia seoptimal mungkin diiringi pengetahuan yang cukup mengenai bidang yang dituju dengan berbagai cara. Sumber daya manusia yang secara efektif harus berkualitas supaya dapat mencapai produktivitas pegawai yang tinggi. Instansi akan selalu berusaha mempertahankan pegawai yang telah mereka rekrut, mereka akan membina dan mengembangkan karier serta jabatannya, sehingga menjadikan pegawai mempunyai sumber daya yang unggul. Dengan segala perbaikan metode kerja, maka pemborosan waktu dan tenaga serta berbagai masukan lainnya dapat ditekan semaksimal mungkin.

Produktivitas kerja merupakan suatu hasil kerja dari seorang pegawai, hasil kerja pegawai merupakan suatu proses bekerja dari seorang pegawai dalam menghasilkan suatu barang dan jasa. Sering terjadi produktivitas kerja pegawai menurun diakibatkan karena berbagai macam faktor, baik dari kedisiplinan kerja , motivasi, pelatihan, upah, maupun faktor-faktor lain. Dalam Kantor Pengadilan Tata Usaha Negara Makassar ada berbagai macam faktor yang dapat mempengaruhi tingkat produktivitas meningkat, namun dalam hal ini peneliti menemukan berdasarkan pengamatan sebelumnya bahwa dalam Kantor Pengadilan Tata Usaha Negara Makassar tingkat kedisiplinan pegawai kurang. Pegawai kadang datang terlambat, cepat pulang dan kadang keluar tampa izin.

Maka dalam hal ini melihat banyaknya faktor-faktor yang dapat mempengaruhi produktivitas kerja pegawai peneliti hanya menfokuskan pada dua variabel yaitu pendidikan dan pelatihan. Selain itu dengan adanya pendidikan dan pelatihan dapat memberikan rasa semakin percaya diri dan menumbuhkan rasa keyakinan pada diri pegawai dalam melakukan pekerjaannya. Dengan demikian, apabila rasa percaya diri telah diwujudkan, maka pegawai tersebut dapat bekerja semaksimal mungkin, sehingga instansi dapat mencapai tujuan yang telah ditetapkan, yaitu produktivitas kerja yang lebih 
Jurnal Ekonomi Balance Fakultas Ekonomi Dan Bisnis

baik. Berdasarkan latar belakang diatas maka penulis tertarik untuk melakukan penelitian dengan judul : Faktor-faktor yang mempengaruhi produktivitas kerja pegawai pada kantor Pengadilan Tata Usaha Negara Makassar

\section{METODE PENELITIAN}

\section{Waktu Dan Tempat Penelitian}

Tempat dan waktu penelitian dilaksanakan pada kantor pengadilan Tata Usaha Negara Makassar yang terletak di jln. Raya Pendidikan No.1 Kota Makassar, waktu penelitian sampai pada perampungan diperkirakan selama dua bulan, terhitung dari bulan April-Mei 2016. Dalam rangka menyatukan persepsi dalam penelitian ini maka dirumuskan defenisi operasinalnya. Defenisi operasional diperlukan untuk menghindari kekeliruan penafsiran pembaca terhadap variabel-variabel atau kata-kata dan istilah-istilah teknis yang terkandung dalam judul. Adapun defenisi operasional dalam penelitian ini adalah: Produktivitas kerja pegawai adalah sikap mental yang selalu mencari perbaikan terhadap apa yang telah ada. Dengan kata lain suatu keyakinan bahwa seseorang dapat melakukan pekerjaan lebih baik hari ini daripada hari kemarin.

Pegawai adalah merupakan masyarakat yang telah memenuhi syarat yang ditentukan dan diangkat langsung oleh instansi yang bersangkutan untuk dipekerjakan dan mempunyai hak serta kewajiban dalam pekerjaanya. Pendidikan adalah suatu proses pengembangan kemampuan ke arah yang diinginkan oleh organisasi. Pelatihan adalah proses meningkatkan kemampuan dan keterampilan pegawai melalui pelaksanaan pendidikan non formal seperti diklat, kursus dan sebagainya. Metode pengumpulan data yang digunakan dalam penelitian ini adalah Penelitian pustaka, Penelitian dimaksudkan untuk mengumpulkan data melalui penjelasan terhadap buku-buku literature yang berhubungan dengan topic dan masalah yang diteliti. Penelitian lapangan Angket dan kuesioner Kuesioner adalah sejumlah pertanyaan tertulis yang digunakan untuk memperoleh informasi dari responden dalam arti laporan tentang pribadinya, atau hal-hal yang ia ketahui, Observasi, yaitu melakukan pengamatan langsung pada pengadilan tata usaha Negara Makassar. 


\section{Metode Analisis Data}

\section{Analisis regresi linear berganda}

Analisis regresi linear berganda digunakan untuk jenis penelitian yang lebih dari satu variabel bebas, dengan menggunakan rumus.

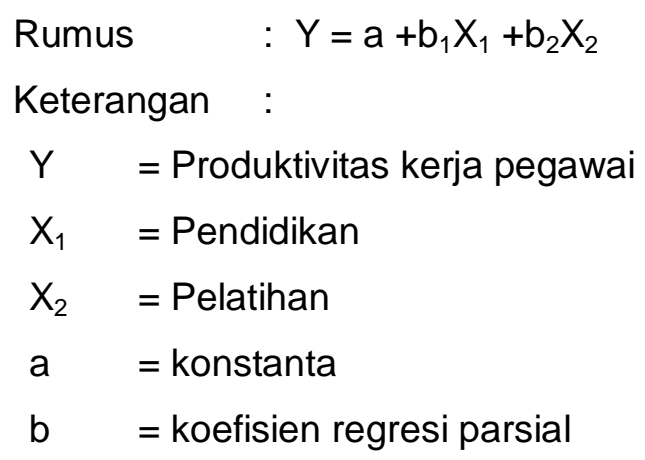

\section{a. Analisis determinasi}

Koefisien determinisasi digunakan untuk mengetahui signifikan determinan menunjukkan besarnya konstribusi variabel bebas $(X)$ terhadap variabel terikat (Y). semakin besar nilai determinasi maka semkain baik kemampuan variabel bebas menerangkang variabel terikat. Jika koefisien determinasi $\left(R^{2}\right)$ semakin besar (mendekati satu), maka dapat dikatakan bahwa pengaruh variabel bebas adalah besar terhadap variabel terikat. Hal ini berarti model yang digunakan semakin kuat untuk menerangkan pengaruh variabel bebas yang diteliti terhadap variabel terikat. Sebaliknya jika determinasi $\left(R^{2}\right)$ semakin kecil ( mendekati 0 ), maka dapat dikatakan bahwa pengaruh variabel bebas terhadap variabel terikat semakin kecil. Hal ini berarti model yang digunakan tidak kuat untuk menerangkan variabel bebas terhadap variabel terikat. Hal ini berarti model yang digunakan tidak kuat untuk menerangkan variabel bebas terhadap variabel terikat.

\section{HASIL DAN PEMBAHASAN}

\section{Hasil Penelitian}

\section{a. Karakteristik Responden}

Sebagai awal proses analisis dalam hasil penelitian ini, dilakukan analisis terhadap karakteristik responden yang dikelompokkan berdasarkan jenis kelamin, umur, jabatan, masa kerja dan tingkat pendidikan.

\section{b. Jenis Kelamin}

Data yang diperoleh dari 50 orang jumlah responden berjenis kelamin lakilaki sebanyak $78 \%$ atau 39 Orang. Sedangkan responden perempuan sebanyak 
$22 \%$ atau 11 orang. Ini berarti dalam penelitian ini responden laki-laki lebih banyak jumlahnya dari pada responden perempuan.

\section{c. Jabatan}

Responden yang paling banyak adalah hakim yatu $28 \%$ atau 14 orang, panitera pengganti $16 \%$ atau 8 orang, juru sita pengganti $12 \%$ atau 6 orang, kasub.bag. umum $12 \%$ atau 6 orang, kasub.bag. kepegawain $8 \%$ atau 4 orang, panmud perkara $6 \%$ atau 3 orang, kasub.bag keuangan $4 \%$ atau 2 orang, panmud hokum $4 \%$ atau 2 orang, Ketua $2 \%$ atau 1 orang, Wakil $2 \%$ atau 1 orang, Sekretaris/Panitera $2 \%$ atau 1 orang, Wakil Panitera $2 \%$ atau 1 orang, Sekretaris $2 \%$ atau 1 orang

\section{d. Tingkat Pendidikan}

Tingkat pendidikan responden dan dari 50 orang, total responden $60 \%$ atau 30 orang Sarjana (S1), 20\% atau 10 orang pasca Sarjana (S2) dan 20\% atau 10 orang yang berpendidikan SMA/Sederajat. Dari data tersebut dapat diambil kesimpulan bahwa responden pegawai Pengadilan Tata Usaha Negara Makassar sebagian besar bertingkat pendidikan Sarjana (S1).

\section{e. Umur}

Pegawai yang berusia di bawah 21-30 tahun ada 7 orang (14\%), berusia antara 31-35 tahun ada 4 orang (8\%) yang berusia antara 36-40 tahun ada 7 orang (14\%), yang berusia diatas 40 tahun ada 32 orang (64\%). Dari data tersebut dapat diambil kesimpulan bahwa responden pegawai Pengadilan Tata usaha Negara Makassar sebagian besar besar berusia diatas 40 tahun.

\section{f. Masa Keja}

Masa kerja dapat dijelaskan bahwa 14 orang (28\%) bekerja selama 5-10 tahun, 28 orang (56\%) bekerja selama $11-20$ Tahun, 8 orang (16\%) bekerja selama 21 tahun keatas. Dari data tersebut dapat diambil kesimpulan bahwa responden Pengadilan tata Usaha Negara Makassar raa-rata memiliki masa kerja 11-20 tahun.

\section{Analisis Statistik Deskriptif}

Pada bagian ini akan disajikan data berdasarkan dimensi dalam bentuk tabel distribusi frekuensi. Hal ini untuk memudahkan dalam membaca hasil penelitian yan telah dilakukan. Adapun data untuk membuat tabel tersebut diperoleh dari hasil pengolahan data kuesioner menggunakan SPSS 23 dengan melihat tingkat frekuensi responden dalam memilih jawaban yang tersedia. Opsi- 
opsi jawaban yang tersedia adalah Sangat Tidak Setuju (STS), Tidak Setuju (TS), Kurang Setuju (KS), Setuju (S), dan Sangat Setuju (SS).

\section{a. Variabel Pendidikan $\left(X_{1}\right)$}

Distribusi jawaban responden mengenai variabel pelatihan :

1) Saya bersemangat (antusias) dalam mengikuti pendidikan. Sebagian besar responden memberikan pernyataan sangat setuju yaitu sebesar $78 \%$ atau 39 orang, pada bagian setuju yaitu $22 \%$ atau 11 orang. Dengan demikian dapat disimpulkan bahwa pegawai pada kantor Pengadilan Tata Usaha Negara Makassar yang mengikuti pendidikan mengatakan bersemangat (antusias) dalam mengikuti Pendidikan.

2) Saya berpartisipasi aktif dalam kegiatan-kegiatan selama Pendidikan.Responden terbanyak memberikan pernyataan sangat setuju yaitu $52 \%$ atau 26 orang dan pada bagian setuju ada $48 \%$ atau 24 orang. Dengan demikian dapat disimpulkan bahwa pegawai pada kantor Pengadilan Tata Usaha Negara Makassar yang mengikuti Pendidikan mengatakan selalu berpartisipasi aktif terhadap kesempatan yang diberikan kepada peserta.

3) Saya mendapatkan materi Pendidikan sesuai dengan kebutuhan pekerjaan. Responden terbanyak memberikan pernyataan sangat setuju yaitu $60 \%$ atau 30 orang dan pada bagian setuju ada $26 \%$ atau 13 orang, pada bagian kurang setuju ada $14 \%$ atau 7 orang. Dengan demikian dapat disimpulkan bahwa pegawai pada kantor Pengadilan Tata Usaha Negara Makassar yang mengikuti Pendidikan mengatakan materi yang disampaikan sesuai dengan kebutuhan pekerjaan. Materi yang diberikan dalam Pendidikan memudahkan saya dalam mengerjakan tugas yang diberikan. Responden terbanyak memberikan pernyataan sangat setuju yaitu $78 \%$ atau 39 orang dan pada bagian setuju ada $22 \%$ atau 11 orang. Dengan demikian dapat disimpulkan bahwa pegawai pada kantor Pengadilan Tata Usaha Negara Makassar yang mengikuti Pendidikan mengatakan materi yang diberikan memudahkan peserta untuk mengerjakan tugas yang diberikan.

4) Metode yang digunakan dalam Pendidikan mempermudah saya dalam memahami materi Diklat.

Responden terbanyak memberikan pernyataan sangat setuju yaitu $52 \%$ atau 26 orang dan pada bagian setuju ada $48 \%$ atau 24 orang. Dengan demikian dapat disimpulkan bahwa pegawai pada kantor Pengadilan Tata Usaha Negara 
Makassar yang mengikuti Pendidikan mengatakan materi yang disampaikan mudah dipahami oleh peserta.

\section{b. Variabel Pelatihan $\left(\mathbf{X}_{2}\right)$}

Distribusi jawaban responden mengenai variabel pelatihan :

1) Saya memahami tujuan dari pelatihan yang diberikan oleh Badan Diklat

Tabel 5.11

\begin{tabular}{|l|l|r|r|r|r|}
\hline \multicolumn{7}{|c|}{ Indikator 1 } \\
\hline \multirow{2}{*}{} & Frequency & $\begin{array}{c}\text { Perce } \\
\text { nt }\end{array}$ & \multicolumn{1}{|c|}{$\begin{array}{c}\text { Valid } \\
\text { Percent }\end{array}$} & $\begin{array}{r}\text { Cumulativ } \\
\text { e Percent }\end{array}$ \\
\hline \multirow{3}{*}{ Valid } & setuju & 21 & 42.0 & 42.0 & 42.0 \\
\cline { 2 - 6 } & sangat setuju & 29 & 58.0 & 58.0 & 100.0 \\
\cline { 2 - 7 } & Total & 50 & 100.0 & 100.0 & \\
\hline
\end{tabular}

Sumber : Data Diolah SPSS 23, 2016

Berdasarkan tabel di atas menunjukkan bahwa sebagian besar responden memberikan pernyataan sangat setuju yaitu sebesar $58 \%$ atau 29 orang, pada bagian setuju yaitu $42 \%$ atau 21 orang. Dengan demikian dapat disimpulkan bahwa pegawai pada kantor Pengadilan Tata Usaha Negara Makassar yang mengikuti pelatihan mengatakan selama pelatihan berlangsung peserta sangat memahami tujuan pelatihan yang diberikan oleh Badan Diklat.

2) Saya merasa nyaman saat Pelatihan diberikan.

Tabel 5.12

\begin{tabular}{|c|c|c|c|c|c|}
\hline \multicolumn{6}{|c|}{ Indikator 2} \\
\hline & & $\begin{array}{c}\text { Frequen } \\
\text { cy }\end{array}$ & Percent & $\begin{array}{c}\text { Valid } \\
\text { Percent }\end{array}$ & Cumulative Percent \\
\hline \multirow[t]{4}{*}{$\begin{array}{l}\text { Va } \\
\text { lid }\end{array}$} & $\begin{array}{l}\text { kurang } \\
\text { setuju }\end{array}$ & 7 & 14.0 & 14.0 & 14.0 \\
\hline & setuju & 13 & 26.0 & 26.0 & 40.0 \\
\hline & $\begin{array}{l}\text { sangat } \\
\text { setuju }\end{array}$ & 30 & 60.0 & 60.0 & 100.0 \\
\hline & Total & 50 & 100.0 & 100.0 & \\
\hline
\end{tabular}

Sumber : Data Diolah SPSS 23, 2016

Berdasarkan tabel di atas menunjukkan bahwa sebagian besar responden memberikan pernyataan sangat setuju yaitu sebesar $60 \%$ atau 30 orang, pada 
Jurnal Ekonomi Balance Fakultas Ekonomi Dan Bisnis

bagian setuju yaitu $26 \%$ atau 13 orang dan pada bagian netral yaitu $14 \%$ atau 7 orang. Dengan demikian dapat disimpulkan bahwa pegawai pada kantor Pengadilan Tata Usaha Negara Makassar yang mengikuti pelatihan mengatakan nyaman saat mengikuti pelatihan.

Tabel 5.13

\begin{tabular}{|l|l|r|r|r|r|}
\hline \multicolumn{7}{|c|}{ Indikator 3 } \\
\hline \multirow{2}{*}{} & $\begin{array}{c}\text { Frequen } \\
\text { cy }\end{array}$ & $\begin{array}{c}\text { Perc } \\
\text { ent }\end{array}$ & $\begin{array}{c}\text { Valid } \\
\text { Percent }\end{array}$ & $\begin{array}{c}\text { Cumulative } \\
\text { Percent }\end{array}$ \\
\hline Valid & setuju & 19 & 38.0 & 38.0 & 38.0 \\
\cline { 2 - 6 } & sangat & 31 & 62.0 & 62.0 & 100.0 \\
& setuju & & & & \\
\cline { 2 - 7 } & Total & 50 & 100.0 & 100.0 & \\
\hline
\end{tabular}

Sumber : Data Diolah SPSS 23, 2016

Berdasarkan tabel di atas menunjukkan bahwa sebagian besar responden memberikan pernyataan sangat setuju yaitu sebesar $62 \%$ atau 31 orang, pada bagian setuju yaitu $38 \%$ atau 19 orang. Dengan demikian dapat disimpulkan bahwa pegawai pada kantor Pengadilan Tata Usaha Negara Makassar yang mengikuti pelatihan mengatakan peserta mendapatkan fasilitas yang memadai selama pelatihan berlangsung. Pelatihan yang saya dapatkan sangat bermanfaat untuk meningkatkan kemampuan dan keterampilan saya.

Tabel 5.14

\begin{tabular}{|l|l|r|r|r|r|}
\hline \multicolumn{7}{|c|}{ Indikator 4} \\
\hline \multirow{2}{*}{} & $\begin{array}{c}\text { Frequen } \\
\text { cy }\end{array}$ & $\begin{array}{c}\text { Perc } \\
\text { ent }\end{array}$ & \multicolumn{1}{c|}{$\begin{array}{c}\text { Valid } \\
\text { Percent }\end{array}$} & $\begin{array}{c}\text { Cumulative } \\
\text { Percent }\end{array}$ \\
\hline \multirow{3}{*}{ Valid } & setuju & 21 & 42.0 & 42.0 & 42.0 \\
\cline { 2 - 7 } & sangat setuju & 29 & 58.0 & 58.0 & 100.0 \\
\cline { 2 - 7 } & Total & 50 & 100.0 & 100.0 & \\
\hline
\end{tabular}

Sumber : Data Diolah SPSS 23, 2016

Berdasarkan tabel di atas menunjukkan bahwa sebagian besar responden memberikan pernyataan sangat setuju yaitu sebesar $58 \%$ atau 29 orang, pada bagian setuju yaitu $42 \%$ atau 21 orang. Dengan demikian dapat disimpulkan bahwa pegawai pada kantor Pengadilan Tata Usaha Negara Makassar yang mengikuti pelatihan mengatakan bahwa pelatihan yang didapatkan oleh peserta 
sangat bermanfaat untuk meningkatkan kemampuan dan keterampilan peserta. Setelah saya mengikuti pelatihan, saya dapat menyelesaikan pekerjaan dengan cepat dan tepat sesuai dengan ketentuan.

Tabel 5.15

\begin{tabular}{|c|l|r|r|r|r|}
\hline \multicolumn{7}{|c|}{ Indikator 5 } \\
\hline \multicolumn{2}{|c|}{} & Frequency & $\begin{array}{c}\text { Perc } \\
\text { ent }\end{array}$ & $\begin{array}{c}\text { Valid } \\
\text { Percent }\end{array}$ & \multicolumn{2}{c|}{$\begin{array}{c}\text { Cumulative } \\
\text { Percent }\end{array}$} \\
\hline \multirow{2}{*}{$\begin{array}{l}\text { Va } \\
\text { lid }\end{array}$} & $\begin{array}{l}\text { kurang } \\
\text { setuju }\end{array}$ & 7 & 14.0 & 14.0 & 14.0 \\
\cline { 2 - 7 } & setuju & 13 & 26.0 & 26.0 & 100.0 \\
\cline { 2 - 7 } & $\begin{array}{l}\text { sangat } \\
\text { setuju }\end{array}$ & 30 & 60.0 & 60.0 & \\
\cline { 2 - 7 } & Total & 50 & 100.0 & 100.0 & \\
\hline
\end{tabular}

Sumber : Data Diolah SPSS 23, 2016

Berdasarkan tabel di atas menunjukkan bahwa sebagian besar responden memberikan pernyataan sangat setuju yaitu sebesar $60 \%$ atau 30 orang, pada bagian setuju yaitu $26 \%$ atau 13 orang dan pada bagian kurang setuju $14 \%$ atau 7 orang. Dengan demikian dapat disimpulkan bahwa pegawai pada kantor Pengadilan Tata Usaha Negara Makassar yang mengikuti pelatihan mengatakan peserta dapat menyelesaikan pekerjaan dengan cepat dan tepat sesuai dengan ketentuan.

\section{c. Variabel Produktivitas Kerja (Y)}

Distribusi jawaban responden mengenai variabel produktivitas kerja : Saya selalu hadir setiap saat sesuai jadwal kerja untuk melaksanakan pekerjaan saya.

\begin{tabular}{|l|l|r|r|r|r|}
\hline \multicolumn{7}{|c|}{ Tabel 5.16 Indikator 1 } \\
\hline \multicolumn{2}{|c|}{} & $\begin{array}{c}\text { Frequen } \\
\text { cy }\end{array}$ & $\begin{array}{c}\text { Perce } \\
\text { nt }\end{array}$ & $\begin{array}{c}\text { Valid } \\
\text { Percent }\end{array}$ & Cumulative Percent \\
\hline \multirow{2}{*}{$\begin{array}{l}\text { Vali } \\
\text { d }\end{array}$} & $\begin{array}{l}\text { kurang } \\
\text { setuju }\end{array}$ & 11 & 22.0 & 22.0 & 22.0 \\
\cline { 2 - 7 } & setuju & 21 & 42.0 & 42.0 & 64.0 \\
\cline { 2 - 7 } & $\begin{array}{l}\text { sangat } \\
\text { setuju }\end{array}$ & 18 & 36.0 & 36.0 & 100.0 \\
\cline { 2 - 7 } & Total & 50 & 100.0 & 100.0 & \\
\hline
\end{tabular}

Sumber : Data Diolah SPSS 23, 2016 
Berdasarkan tabel di atas responden terbanyak menyatakan setuju yaitu sebesar $42 \%$ atau 21 orang, pada bagian sangat setuju yaitu $36 \%$ atau 18 orang dan pada bagian kurang setuju $22 \%$ atau 11 orang. Hal ini menandakan bahwa hampir seluruh responden selalu hadir setiap saat sesuai jadwal kerja melaksanakan pekerjaanya. Saya mampu menyelesaikan tugas tepat waktu dalam melakukan pekerjaan Sebagian besar responden memberikan pernyataan sangat setuju yaitu sebesar $58 \%$ atau 29 orang, pada bagian setuju yaitu $42 \%$ atau 21 orang. Hal ini menandakan bahwa hampir seluruh responden mampu menyelesaikan tugas tepat waktu. Saya dapat menyelesaikan tugas sebaikbaiknya dengan berusaha meminimalisasi kelalaian kerja.

\begin{tabular}{|l|l|r|r|r|r|}
\hline \multicolumn{7}{|c|}{ Tabel 5.18 Indikator 3 } \\
\hline \multirow{7}{*}{} & $\begin{array}{c}\text { Frequen } \\
\text { cy }\end{array}$ & $\begin{array}{c}\text { Perce } \\
\text { nt }\end{array}$ & $\begin{array}{c}\text { Valid } \\
\text { Percent }\end{array}$ & $\begin{array}{c}\text { Cumulative } \\
\text { Percent }\end{array}$ \\
\hline Valid & setuju & 32 & 64.0 & 64.0 & 64.0 \\
\cline { 2 - 6 } & sangat & 18 & 36.0 & 36.0 & 100.0 \\
& setuju & & & & \\
\cline { 2 - 7 } & Total & 50 & 100.0 & 100.0 & \\
\hline
\end{tabular}

Sumber : Data Diolah SPSS 23, 2016

Berdasarkan tabel di atas menunjukkan bahwa sebagian besar responden memberikan pernyataan setuju yaitu sebesar $64 \%$ atau 32 orang, pada bagian sangat setuju yaitu $36 \%$ atau 18 orang. Hal ini berarti sebagian besar responden dapat dapat menyelesaikan tugas sebaik-baiknya dengan berusaha meminimalisasi kelalaian kerja. Saya dapat bekerjasama dengan rekan kerja untuk memberikan pelayanan pada kantor pengadilan tata usaha Negara makasaar. 


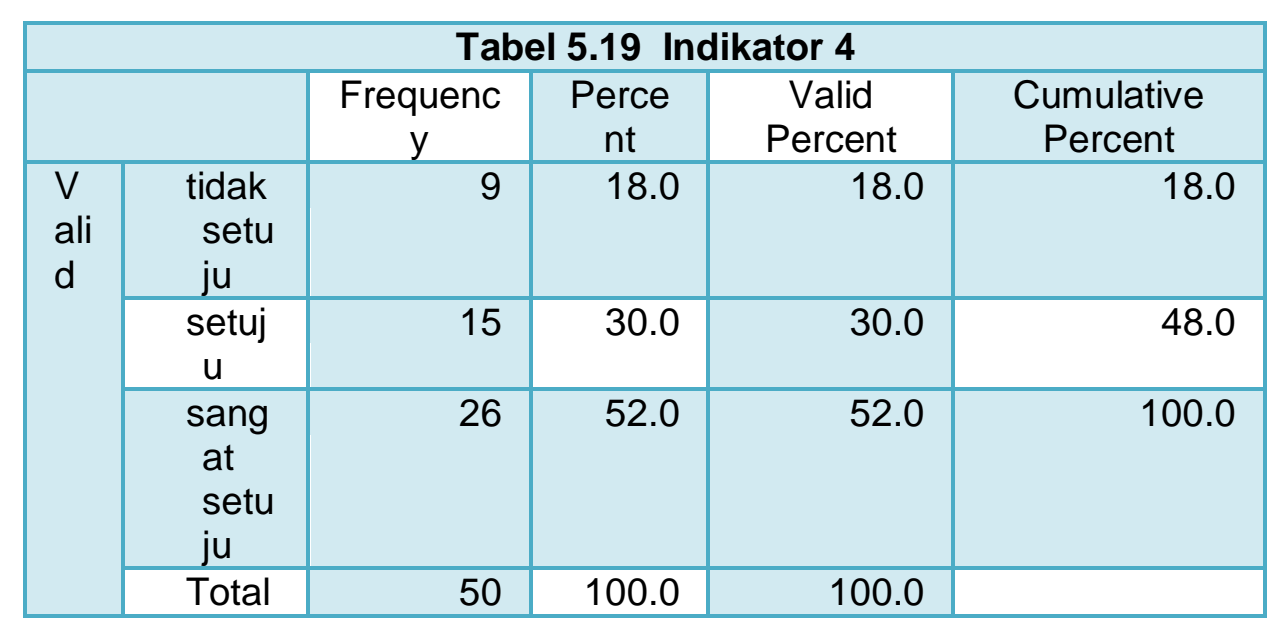

Sumber : Data Diolah SPSS 23, 2016

Berdasarkan tabel di atas menunjukkan bahwa sebagian besar responden memberikan pernyataan sangat setuju yaitu sebesar $52 \%$ atau 26 orang, pada bagian setuju yaitu $30 \%$ atau 15 orang dan pada bagian kurang setuju $18 \%$ atau 9 orang. Hal ini berarti responden dapat bekerja sama dengan rekan kerja untuk memberikan pelayanan pada kantor Pengadilan Tata Usaha Negara Makassar. Namun ada pula responden yang menyatakan tidak setuju sebanyak $18 \%$ atau 9 orang.

\section{Analisis Data}

\section{a. Analisis Validitas}

Suatu instrument dikatakan valid jika instrument ini mampu mengukur apa saja yamg hendak diukurnya, mampu mengungkapkan apa yang ingin diungkapkan. Besarnya $r$ tiap butir pertanayaan dapat dilihat dari hasil analisis SPSS 23 pada kolom Corrected items Total correlation. kriteria uji validasi secara singkat (rule of tumb) adalah 0.30 , jika kolerasi sudah lebih besar dari 0.00 , berarti butir pertanyaan tersebut valid.

\begin{tabular}{|r|r|r|r|r|}
\hline \multicolumn{5}{|c|}{ Tabel 5.20 Item-Total Statistics } \\
\hline & $\begin{array}{r}\text { Scale Mean if } \\
\text { Item Deleted }\end{array}$ & $\begin{array}{l}\text { Scale Variance } \\
\text { if Item Deleted }\end{array}$ & $\begin{array}{r}\text { Corrected } \\
\text { Item-Total } \\
\text { Correlation }\end{array}$ & $\begin{array}{r}\text { Cronbach's } \\
\text { Alpha if Item } \\
\text { Deleted }\end{array}$ \\
\hline X1 & 58.22 & 42.093 & .785 & .946 \\
-1 & 58.48 & 41.602 & .718 & .946 \\
\hline X1 & & & & \\
\hline 2 & & & & \\
\hline
\end{tabular}


Jurnal Ekonomi Balance Fakultas Ekonomi Dan Bisnis

Volume 13 No 1 Tahun 2017

\begin{tabular}{|c|c|c|c|c|}
\hline $\begin{array}{r}X 1 \\
-3\end{array}$ & 58.54 & 38.376 & .837 & .943 \\
\hline $\begin{array}{r}X 1 \\
-4\end{array}$ & 58.22 & 42.093 & .785 & .946 \\
\hline $\begin{array}{r}X 1 \\
-5\end{array}$ & 58.48 & 41.602 & .718 & .946 \\
\hline $\begin{array}{r}\text { X2 } \\
-1\end{array}$ & 58.42 & 41.106 & .810 & .945 \\
\hline $\begin{array}{r}X 2 \\
2\end{array}$ & 58.54 & 37.804 & .907 & .941 \\
\hline $\begin{array}{r}X 2 \\
-3\end{array}$ & 58.38 & 41.955 & .683 & .947 \\
\hline $\begin{array}{r}X 2 \\
-4\end{array}$ & 58.42 & 41.106 & .810 & .945 \\
\hline $\begin{array}{r}X 2 \\
-5\end{array}$ & 58.54 & 37.804 & .907 & .941 \\
\hline $\mathrm{Y} 1$ & 58.86 & 38.327 & .815 & .944 \\
\hline Y2 & 58.42 & 42.330 & .609 & .949 \\
\hline Y3 & 58.64 & 42.113 & .665 & .948 \\
\hline Y4 & 58.84 & 35.566 & .733 & .953 \\
\hline
\end{tabular}

sumber : Data diolah SPSS 23, 2016

\section{b. Analisis Reliabilitas}

Reliabilitas menunjukkan suatu instrument yang dapat digunakan sebagai alat pengumpul data, karena instrumen dapat dipercaya dan reliable yang akan menghasilkan data yang dapat dipercaya. Suatu instrument dikatakan reliabel apabila memiliki nilai Cronbach's alpha $(\alpha)>0,60$.

Tabel 5.21

Hasil uji reabilitas variabel Pendidikan $\left(\mathrm{X}_{1}\right)$

\begin{tabular}{|r|r|}
\hline \multicolumn{3}{|c|}{ Reliability Statistics } \\
\hline Cronbach's Alpha & N of Items \\
\hline .882 & \\
\hline
\end{tabular}

Sumber : Data diolah SPSS 23, 2016 
Jurnal Ekonomi Balance Fakultas Ekonomi Dan Bisnis

Volume 13 No 1 Tahun 2017

Berdasarkan tabel hasil uji reliabilitas variabel $X_{1}$ di atas hasil pengolahan data mengenai reliabilitas dianggap reliable sebab nilai Cronbach's alpha suadh diatas 0,60 .

Tabel 5.22

Hasil uji reabilitas variabel Pelatihan $\left(X_{2}\right)$

\begin{tabular}{|c|c|}
\hline \multicolumn{2}{|c|}{ Reliability Statistics } \\
\hline $\begin{array}{l}\text { Cronbach's } \\
\text { Alpha }\end{array}$ & $\mathrm{N}$ of Items \\
\hline .925 & 5 \\
\hline
\end{tabular}

Berdasarkan tabel hasil uji reliabilitas variabel $\mathrm{X}_{2}$ di atas, nilai Cronbach's Alpha mencapai angka 0,925 yaitu lebih besar dari 0,60. Berdasrkan ketentuan di atas maka indicator-indikator dalam penelitian dikatakan reliable.

\section{Tabel 5.23}

\section{Hasil uji reabilitas variabel Produktivitas Kerja (Y)}

\begin{tabular}{|r|r|}
\hline \multicolumn{2}{|c|}{ Reliability Statistics } \\
\hline $\begin{array}{c}\text { Cronbach's } \\
\text { Alpha }\end{array}$ & N of Items \\
\hline .818 & 4 \\
\hline
\end{tabular}

Sumber : Data diolah SPSS 23, 2016

Berdasarkan tabel hasil uji reabilitas variabel $Y$ di atas, nilai Cronbach's Alpha mencapai angka sebesar 0,818 yaitu lebih besar dari 0,60. Berdasarkan ketentuan di atas maka indikator-indikator dalam penelitian dikatakan reliable.

\section{Model Persamaan Regresi}

\section{a. Hasil Analisis Regresi Berganda}

Analisis regresi berganda digunakan dalam menguji seberapa besar pengaruh antara pendidikan dan pelatihan terhadap produktivitas kerja pegawai. Oleh karena itu akan disajikan hasil olahan data regresi yang dapat dilihat pada tabel berikut ini : 
Jurnal Ekonomi Balance Fakultas Ekonomi Dan Bisnis

Tabel 5.24

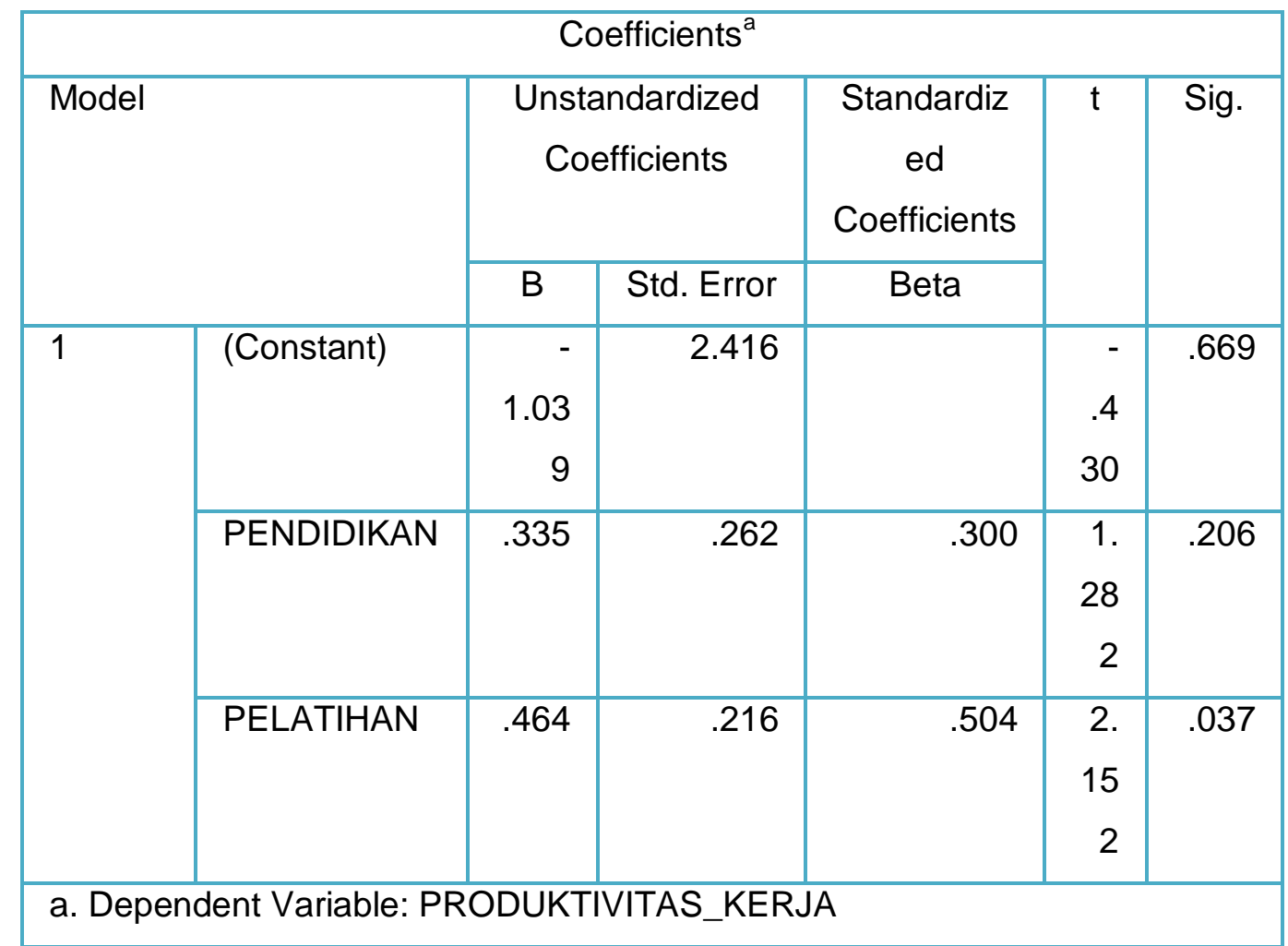

Sumber : Data diolah SPSS 23, 2016

Setelah dilakukan perhitungan dengan menggunakan program computer SPSS versi 23 maka diperoleh persamaan sebagai berikut :

$$
Y=-1.039+0,335 X_{1}+0,464 X_{2}
$$

Persamaan regresi tersebut dapat dijelaskan sebagai berikut :

$a=-1.039$ bernilai negatif, yang menunjukkan arah yang negatif. Hal ini menunjukkan bahwa jika dalam penelitian tidak dicantumkan variabel $X_{1}$ dan $X_{2}$ maka produktivitas kerja pegawai $(Y)$ akan mengalami penurunan atau tidak terdapat peningkatan.

$\mathrm{b}_{1}=0,335$ menunjukkan bahwa variabel pendidikan $\left(\mathrm{X}_{1}\right)$ berpengaruh positif terhadap produktivitas kerja pegawai. Dengan kata lain, dilihat dari persamaan di atas berarti pendidikan akan meningkatkan prdoktivitas kerja pegawai.

$\mathrm{b}_{2}=0,464$ menunjukkan bahwa variabel pelatihan $\left(\mathrm{X}_{2}\right)$ berpengaruh positif terhadap produktivitas kerja pegawai. Dengan kata lain, dilihat dari persamaan di atas berarti pelatihan akan meningkatkan prdoktivitas kerja pegawai. 


\section{b. Analisis Korelasi}

Hasil analisis pengaruh pendidikan dan pelatihan terhadap produktivitas kerja pegawai Pengadilan Tata Usaha Negara Makassar seperti yang dapat dilihat pada tabel $\mathbf{5 . 2 5}$ di atas menunjukkan bahwa koefisien korelasi $(R)=0,789$. Hal ini berarti pendidikan dan pelatihan sangat berhubungan erat dengan produktivitas kerja pegawai karena nilai $R=0.789$.

\section{c. Koefisien Determinasi}

Koefisien determinasi dengan $\mathrm{R}$ menunjukkan indeks kecocokan yang menyatakan proporsi dan variasi total $Y$ (variabel dependen) yang dapat diterangkan oleh $X$ (variabel independen) dan sebagai ukuran hubungan yang linier, yang menyatakan seberapa baik garis regresi cocok dengan data. Nilai koefisien determinasi (R-square) yang digunakan untuk mengetahui persentase pengaruh variabel independen $\left(X_{1}\right.$ dan $\left.X_{2}\right)$ terhadap variabel dependen $(Y)$ sebesar 0,623 . Hal ini berarti bahwa faktor-faktor pendidikan dan pelatihan dapat menjelaskan $62,3 \%$ dari perubahan produktivitas kerja pegawai dan sisanya yaitu sebesar $37,7 \%$ dipengaruhi oleh faktor-faktor yang tidak diteliti.

\section{Uji F dan Uji $t$}

\section{Tabel 5.26}

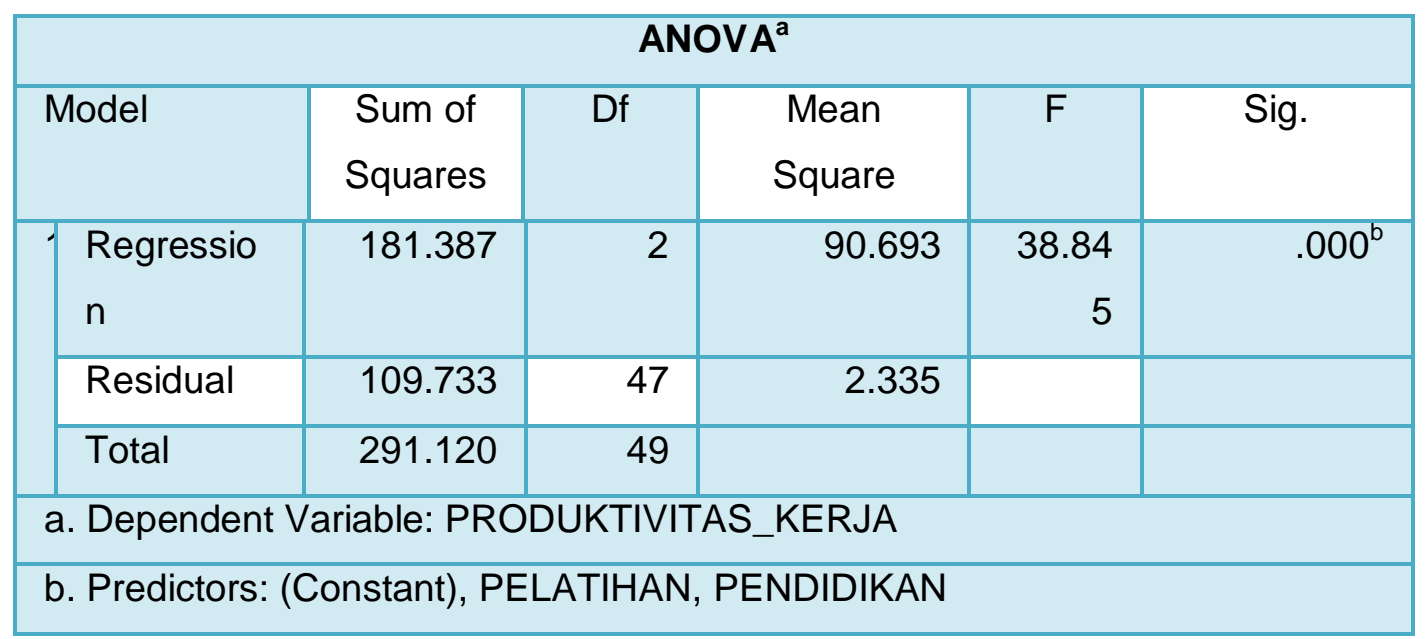

\section{Sumber : Data diolah SPSS 23, 2016}

Tabel 5.26 tersebut menunjukkan hasil daru uji-f yang menghasilkan $F_{\text {hitung }}$ sebesar 38.845 sedangkan untuk menentukan nilai $F_{\text {tabel }}$ pada tingkat kesalahan $5 \%$ atau $a=0,05$ dengan $\mathrm{df} 1=\mathrm{k}-1$ atau $3-1=2$ dan $\mathrm{df} 2=\mathrm{n}-\mathrm{k}$ atau 50-3 = 47, sehingga didapatkan $F_{\text {tabel }}=3.195$. Berdasarkan hasil perhitungan tersebut terlihat bahwa $F_{\text {hitung }}>F_{\text {tabel }}(38.845>3.195)$, sehingga diketahui bahwa $\mathrm{Ha}$ diterima dan Ho ditolak. 
Oleh karena itu dapat disimpulkan bahwa variabel-variabel pendidikan dan pelatihan berpengaruh secara signifikan terhadap produktivitas kerja pegawai pada Pengadilan Tata Usaha Negara Makassar. Berdasrkan uji F, maka hipotesis dalam penelitian ini yang menduga bahwasanya pendidikan dan pelatihan. berpengaruh signifikan terhadap produktivitas kerja pegawai pada Pengadilan Tata Usaha Negara Makassar telah terbukti dan dapat diterima.

\section{a. Uji t}

Untuk uji signifikan pengaruh pendidikan dan pelatihan terhadap produktivitas kerja pegawai digunakan uji-t (uji stundent) atau uji parsial dan uji-f (uji fhiser) atau uji simultan. Digunakan untuk menguji tingkat signifikan variabel $X$ terhadap $Y$. sampel yang digunakan sebanyak 50 orang, sehingga pengujian menggunakan uji $\mathrm{T}$ dengan $\mathrm{df}=\mathrm{n}-2$ atau $\mathrm{df}=48$ dan tingkat signifikan $(\alpha)=5 \%$ maka diperoleh $T_{\text {tabel }}$ sebesar 2.010. Dari tabel diatas dapat dijelaskan sebagai berikut :

1. Nilai $t_{\text {hitung }}$ untuk variabel pendidikan $\left(X_{1}\right)$ adalah sebesar 1.282 sedangkan $t_{\text {tabel }}$ dengan taraf $(a)=0,05$ dengan $\mathrm{df}=\mathrm{n}-2$ atau $\mathrm{df}=48$ adalah sebesar 2.010 .

Dan tingkat signifikannya adalah $0,206>0.05$. Berdasarkan kriteria pengujiannya, maka $t_{\text {hitung }}<t_{\text {tabel }}$ sehingga Ho diterima dan Ha ditolak.

2. Nilai $t_{\text {hitung }}$ untuk variabel pelatihan $\left(X_{2}\right)$ adalah sebesar 2.152 sedangkan $t_{\text {tabel }}$ dengan taraf $(a)=0,05$ dengan $d f=n-2$ atau $d f=48$ adalah sebesar 2.010 . Dan tingkat signifikannya adalah 0,037 < 0,05. Berdasarkan kriteria pengujiannya, maka $t_{\text {hitung }}>t_{\text {tabel }}$ sehingga Ha diterima dan Ho ditolak.

\section{Pembahasan}

Berdasarkan hasil pengolahan data SPSS di atas, penelitian ini menunjukkan variabel pendidikan dan pelatihan mempunyai pengaruh secara signifikan terhadap produktivitas kerja, dimana pada tabel 1.15 uji $F(\alpha=5 \%)$ sebesar $F_{\text {hitung }} 38.845>F_{\text {tabel }}$ 3.195. Hasil penelitian ini menunjukkan bahwa ternyata pendidikan dan pelatihan menjadi faktor yang signifikan terhadap produktivitas kerja pegawai. Artinya Dimana para karyawan yang mengikuti pendidikan dan pelatihan merasa nyaman dan dapat memahami apa yang disampaikan oleh instruktur sehingga dapat mengaplikasikan apa yang mereka peroleh atau ketahui selama mengikuti pelatihan dalam melaksanakan tugas dan pekerjaan mereka. 
Dari hasil parsial (uji t) menggunakan SPSS di atas juga dapat dilihat bahwa variabel pendidikan tidak terlalu berpengaruh signifikan terhadap produktivitas kerja pegawai pada Pengadilan Tata Usaha Negara Makassar. Sedangkan variabel pelatihan berpengaruh signifikan terhadap produktivitas kerja pegawai pada Pengadilan Tata Usaha Negara Makassar.

\section{PENUTUP}

\section{Simpulan}

Berdasarkan hasil analisis dan pembahasan pada bab sebelumnya maka dapat disimpulkan :

1. Hasil uji regresi yang diolah dengan menggunakan program SPSS diperoleh suatu persamaan yaitu :

$Y=-1.039+0,335 X_{1}+0,464 X_{2}$

Dari persamaan tersebut terlihat bahwa kedua variabel yang diteliti yaitu pendidikan $\left(\mathrm{X}_{1}\right)$ dan pelatihan $\left(\mathrm{X}_{2}\right)$ berpegaruh positif terhadap produktivitas kerja pegawai.

2. Faktor-faktor pendidikan dan pelatihan mempunyai pengaruh signifikan terhadap produktivitas kerja pegawai pada Pengadilan Tata Usaha Negara Makassar yang ditunjukkan dengan hasil uji $F$, nilai $F_{\text {hitung }}$ sebesar 38.845 (signifikan $F=0,000)$. Jadi $F_{\text {hitung }}>F_{\text {tabel }}(38.845>3.195)$ yang berarti dapat disimpulkan $\mathrm{H}_{\mathrm{a}}$ diterima dan $\mathrm{H}_{0}$ ditolak. Dan tingkat signifikan $\mathrm{F}<5 \%(0,000$ $<0,05)$, artinya bahwa secara simultan atau bersama-sama variabel pendidikan dan pelatihan berpenaruh signifikan terhadap variabel produktivitas kerja pegawai.

3. Uji t pendidikan $\left(\mathrm{X}_{1}\right)$ terhadap produktivitas kerja pegawai

Berdasarkan kriteria pengujiannya, maka $t_{\text {hitung }}<t_{\text {tabel, }}$ sehingga Ho diterima dan $\mathrm{Ha}$ ditolak. Yang berarti pendidikan secara parsial tidak berpengaruh signifikan terhadap produktivitas kerja pegawai. Uji t pelatihan $\left(\mathrm{X}_{2}\right)$ terhadap produktivitas kerja pegawai, Berdasarkan kriteria pengujiannya, maka $t_{\text {hitung }}>$ $t_{\text {tabel, }}$ sehingga Ha diterima dan Ho ditolak, Yang berarti pelatihan secara parsial berpengaruh signifikan terhadap produktivitas kerja pegawai.

4. Berdasarkan analisis korelasi determinasi ( $R$ Squared), sebesar 0,623. Hal tersebut berarti bahwa terdapat pengaruh pendidikan dan pelatihan terhadap produktivitas kerja pegawai sebesar $62,3 \%$ dan sisanya 37,7 dipengaruhi oleh faktor-faktor yang tidak di teliti. 


\section{Saran}

Berdasarkan hasil penelitian mengenai pengaruh pendidikan dan pelatihan terhadap produktivitas kerja pegawai, maka saran dari penulis yang dianggap perlu kepada instansi, yaitu :

1. Pendidikan dan pelatihan merupakan salah satu upaya dalam meningkatkan sumber daya manusia suatu organisasi agar tercipta sumberdaya manusia yang bermutu. Untuk itu perlu adanya perencanaan peningkatan pengetahuan, kemampuan, dan keterampilan pegawai secara berkala dan berkesinambungan, sesuai dengan kebutuhan pegawai sehingga para pegawai akan dapat menguasai bidang pekerjaannya.

2. Perlu adanya evaluasi yang dilakukan oleh instansi terhadap para pegawai yang sudah mengikuti pendidikan dan pelatihan sehingga dapat mengetahui apa yang telah didapatkan pegawai semasa diklat dan mengetahui apa yang perlu diperbaiki lagi untuk meningkatkan kinerja pegawai.

3. Kesadaran dan tanggung jawab pegawai pada Kantor Pengadilan Tata Usaha Negara Makassar terhadap pekerjaannya harus ditingkatkan lagi, sehingga hasil pekerjaan menjadi lebih maksimal. Dan perlu penempatan pegawai pada bidang pekerjaan yang sesuai dengan bidang kemampuannya untuk mendorong pegawai mencapai kinerjanya menjadi lebih baik sesuai dengan kemampuan yang dimiliki.

4. Bagi Peneliti lain yang akan meneliti pada permasalahan yang sejenis diharapkan memasukan variabel lain diluar variabel yang sudah ada dalam penelitian ini. 


\section{DAFTAR PUSTAKA}

Andrew E. Sikula. 1981. "Pelatihan dan Pengembangan Tenaga Kerja". Jakarta : Pustaka Binaman.

Anwar. 2003. "Hubungan Pendidikan dan Pelatihan Kerja Produktivitas Kerja Karyawan di Perusahaan Keramik Soekardi Malang". Skripsi.

Anwar Prabu Mangkunegara. 2011. "Perencanaan dan Pengembangan Sumber Daya Manusia., Bandung : Refika Aditama.

Anwar Prabu Mangkunegara. 2003. "Manajemen Sumber Daya Manusia". Bandung : Refika Aditama.

Dedi Sukardi. 2008. “Hubungan Pelatihan Kerja Dengan Produktivitas Kerja Karyawan Pada Dinas Penindustrian dan Perdagangan Propinsi jawa barat". Skripsi.

Hariandja, Marihot Tua Efendi. 2002. "Manajemen Sumber Daya Manusia:Pengadaan, Pengembangan, Pengkompensasian dan Peningkatan Produktivitas Pegawai”. Jakarta : Grasindo.

Hasibuan, Melayu SP. 2009. "Manajemen Sumber Daya Manusia”. Jakarta: Bumi Aksara,

Hasibuan, Melayu SP. 2007. "Manajemen Sumber Daya Manusia". Cetakan Kesepuluh". Jakarta : Bumi Aksara.

Hasibuan, Melayu SP. 2005. "Manajemen Sumber Daya Manusia. Edisi Revisi”. Cet.7. Jakarta : Bumi Aksara.

Herjanto. E. 2007. "Manajemen Operasi”. Jakarta : Grasindo.

Kussiriyanto, Bambang. 1993. "Meningkatkan Produktivitas Karyawan”. Jakarta : Pustaka Binama Presindo

Langeved. 2001. "Pendidikan Pancasila dan Kewerganegaraan".

Mardalis. 1993. "Metode Penelitian Suatu Pendekatan Proposal" . Cet.III; Jakarta: Bumi Aksara.

Moh. As'ad. 2000. "Psikologi Industry”. Yokyakarta : Edisi keempat, Liberty.

Moekijat. 2001. "Latihan dan Pengembangan sumber Daya Manusia Perusahaan". cet.2. Bandung : Rosda Karya.

Muchdarsyah Sinungan. 2005. "Produktivitas". Jakarta : Bumi Aksara

Mathis. L. Robert dan Jackson. H.John. 2001. “Manajemen Sumber Daya Manusia". Jakarta : Salemba Empat.

Mathis. L. Robert dan Jackson. H.John. 2002, "Manajemen Sumber Daya Manusia". Edisi Pertama. Jakarta : Salemba Empat.

Nasution, Mulia. 1994. “Teknologi Pendidikan”. Jakarta : Bumi Aksara 